\title{
EL ASIENTO DE LA VERDADERA AUTORIDAD EN LAS INDIAS
}

JOHN H. PARRY, La Audiencia de Nueva Galicia en el Siglo XVI. Estudio sobre el gobierno colonial español. Trad. Eduardo Williams y Rafael Diego Fernández. México, El Colegio de Michoacán- Fideicomiso Teixidor, 1993, $330 \mathrm{pp}$.

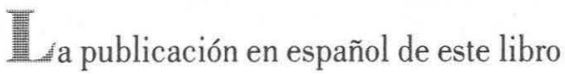
clásico de John H. Parry sobre La Audiencia de Nueva Galicia en el siglo XVI, constituye sin duda un acierto de El Colegio de Michoacán y de Rafael Diego Fernández. Ello no sólo por las dificultades anteriormente existentes para su lectura y consulta (por su desaparición tanto del mercado librero como incluso de las bibliotecas, como lo hace notar Rafael Diego), sino también porque el libro continúa planteando varias interrogantes sobre el gobierno e historia coloniales que es necesario retomar.
Una de las más amplias preguntas lanzadas por Parry tiene que ver con la explicación del ejercicio del poder en las Indias. En palabras del autor, que bien cita Rafael Diego como epígrafe, "la principal dificultad radica en determinar dónde estaba la verdadera autoridad en las Indias" (p. 241), y ello lo comenta Parry no de entrada sino en el capítulo IX sobre "Conflictos de Jurisdicción," porque como lo había anticipado un poco antes: "Los conflictos de jurisdicción fueron la maldición de la administración de las Indias." (p. 239). Conflictos que la historiografía contemporánea se ha preocupado en reseñar ampliamente, quizá siguiendo el modelo original de Parry, pero que desafortunadamente poco nos ha dicho sobre "dónde estaba la verdadera autoridad de las Indias."

Un debate particular sobre las Audiencias tiene que ver sobre sus faculta- 
des como corte de apelaciones con funciones estrictamente judiciales, o bien como gobierno provincial y con funciones administrativas y políticas. Para John $\mathrm{H}$. Parry, sin que haga mención explícita al debate y dado su interés en mostrar el funcionamiento específico y no sólo legal de la Audiencia, ambas funciones están entremezcladas, no obstante que en su fundación las ordenanzas fueran limitantes de la autoridad administrativa, y la audiencia estuviera subordinada al virrey de Nueva España (Cap. II). De hecho, sin embargo, la Audiencia de Nueva Galicia fue fundada como otras para impedir los gobiernos personalizados y conflictivos de los conquistadores y encomenderos, de ahí que una de sus principales funciones haya sido la aplicación de las Leyes Nuevas a partir de los repartimientos de trabajo y la tasación de los tributos, lo cual también tenía que ver con los ingresos de la corona. Estas funciones compartían por lo tanto el carácter judicial, en la aplicación de la ley, como gubernativo. Por cierto, Parry destaca una figura olvidada y maltratada de la historiografía neogallega, al oidor Lorenzo Lebrón de Quiñones por su defensa de los indios en esta región (Cap.III).

La Audiencia de Nueva Galicia también encabezó y promovió, pese a su sujeción al virreinato de la Nueva España, la expansión de la frontera novogallega. Cuando Francisco de Ibarra, sobrino de Diego de Ibarra y uno de los fundadores de Zacatecas, crea el gobierno de la Nueva Vizcaya (1562) bajo la jurisdicción de la Nueva España, los conflictos entre la Audiencia de Nueva Galicia y el virrey se ampliaron. El conflicto a final de cuentas tenía que ver con el manejo de los impuestos ya que Francisco de Ibarra había obtenido concesiones de Nueva España y no de Nueva Galicia (Cap. IV).

"A las audiencias correspondía la poco grata tarea de hacer observar los límites de la jurisdicción episcopal, lo cual era motivo de inevitables conflictos," señala Parry con respecto a las relaciones entre Iglesia y Audiencias. De hecho, la disputa entre ambas instituiciones se dió particularmente entre 1561-1570, debido a que una real cédula le confirió amplios poderes a la Audiencia, de tal forma que un juicio a indios terminó en la excomunión de los oidores. El nombramiento de Francisco Gómez de Mendiola como obispo, habiendo sido oidor, permitió un mayor acercamiento y menos conflictos entre las jurisdicciones, a lo cual también contribuyó el tribunal del Santo Oficio (Cap. V).

John H. Parry dividió su libro en dos grandes apartados, tanto temática como cronológicamente. La primera parte la 
llamó "La Audiencia Subordinada, 15481572," y la segunda "La Audiencia y la Chancillería Real, 1572-1600." Ciertamente, como hemos anotado anteriormente, la subordinación a la Audiencia de la Nueva España existió en los primeros años, aunque como se puede apreciar también la lucha por la independencia administrativa se dio. Este periodo estuvo además caracterizado por una administración colegiada por parte de los oidores, lo cual en la práctica también dificultó la toma de decisiones. Parry identificó bien los años setentas como el momento de los cambios en las funciones de la Audiencia de Nueva Galicia, a partir precisamente de la llegada del virrey Enríquez a la Nueva España (Cap. VI). En 1572 toda la estructura de la Audiencia fue reorganizada, creándose la "Chancillería real" con un presidentegobernador y tres oidores; de acuerdo con Parry, en estos momentos la Audiencia perdió autoridad administrativa o funciones de gobierno, las cuales recuperaría a partir de una cédula de 1574 , al mismo tiempo que ganaba jurisdicción independiente en términos judiciales y ampliaba su territorio. Aunque siempre en la práctica, el Presidente de la Audiencia ejerció poderes administrativos más amplios que los conferidos (Cap.VII).
Como ahora sabemos gracias al excelente estudio de Fernando Muro Romero sobre Las presidencias-gobernaciones en Indias (Siglo XVI) (1975), el cambio importante estuvo en la generalización de los presidentes-gobernadores ya que rompió en buena medida con muchos de los conflictos sobre jurisdicciones; sin embargo, la Audiencia de Nueva Galicia pese a la cédula de 1574 y otras siguió dependiendo del virrey en turno hasta principios del siglo XVII. Desafortunadamente poco sabemos de esta relación con el virreinato para los siglos siguientes, sin embargo se conoce que las disputas continuaron no en téminos estrictamente judiciales sino por la administración de gobierno, el cual formalmente le correspondía al presidente-gobernador de Nueva Galicia.

Precisamente uno de los grandes conflictos de jurisdicción entre la Audiencia de Nueva Galicia y el virrey se encuentra en lo que Tello llamó "la pequeña guerra de Guadalajara." Según Parry, este conflicto iniciado por la prohibición del casamiento de un oidor de Guadalajara, Núñez de Villavicencio, con la hija de uno de los grandes hacendados de la región, Juan Bautista de Lomas y Colmenares, hecho que estaba efectivamente prohibido por la legislación, terminó en una amenaza de guerra y posiblemente en la 
destitución del virrey Villamanrique. Concluye Parry: "El particularismo y celo provincial ya empezaban a jugar un importante papel en la política Latinoamericana." (p. 248) La cita es importante porque más que poner como víctima a la Audiencia de Nueva Galicia, como aún se acostumbra hacer para las regiones, nos habla de un proceso más complejo en el que el poder local de los hombres ricos vinculados a los funcionarios públicos no sólo enfrenta, sino también pone en crisis al poder central. Como bien lo dijo el Dr. Greenleaf en un breve pero excelente artículo sobre esta "guerrita", "el tema del matrimonio de los oidores y fiscales de la corte fue sólo un síntoma del conflicto entre los grandes intereses (de provincia) y el control real." ("The little war of Guadalajara, 1587-1590" New Mexico Historical Review, Vol. XLIII, No. 2, April
1968, p. 128). La relación por lo tanto entre centro y regiones no ha sido históricamente unilineal, como bien nos lo deja ver el excelente estudio de Parry y la adenda del Dr. Greenleaf.

Para regresar a la pregunta inicial de J.H.Parry respecto a dónde residía efectivamente la autoridad en las Indias, me parece que un avance es decir que no necesariamente en el centro, en la corona o en el virrey, lo cual implica cuestionar la vieja idea del centralismo como característica de los sistemas políticos latinoamericanos; quizá en las audiencias y provincias que conformaron el territorio podemos encontrar más pistas, por lo que la relación centro-región, tan vigente en nuestro mundo hispanoamericano, necesita ser revisada.

Víctor M. González Esparza DEPARTAMENTO DE HISTORIA/UAA 